https://doi.org/10.5817/NR2021-1-8

\section{Grzegorz Gazda jako rusista. In memoriam polského teoretika literatury}

Rusistika nebyla hlavním oborem vědecké činnosti nedávno zesnulého Grzegorze Gazdy (13. ř́ijna 1943 - 28. srpna 2020), profesora humanitních věd, historika a teoretika literatury a filmu, odborníka na literaturu holokaustu. Jako absolvent lodžského lycea J.Lelewela vstoupil na Filologickou fakultu Lodžské univerzity, kterou ukončil roku 1966 v oboru polská filologie se specializací filmologie: magisterský titul získal prací o polském poetickém filmu pod vedením prof. Bolesława Lewického, $\mathrm{v}$ letech 1967-1969 byl doktorandem v Polské akademii věd a titul doktora humanitních věd získal roku 1972 prací o polském futurismu za vedení prof. Stefanie Skwarczyńské; mezi recenzenty byl mj. Michał Głowiński. Habilitoval se spisem z dějin evropských avantgard, který recenzoval kromě Stefanie Skwarczyńské také Janusz Sławiński. ${ }^{1}$ A právě těmito posledně uvedenými pracemi nemohl nevstoupit do hájemství ruské literatury.

Takříkajíc zdědil koeditorství genologického časopisu Zagadnienia rodzajów literackich po své učitelce Stefanii Skwarczyňské (1902-1988) a dále $\mathrm{v}$ tom spolupracoval s druhou redakcí, která byla tehdy ve Vratislavi/Wrocławi a již

1 Podrobnější biografické a kariérové informace viz [POSPÍŠIL 2020]. reprezentoval skvělý literární teoretik, genolog a filmolog Jan Trzynadlowski (1912-1995) a později jeho žák Bogdan Pięczka (1935-2004).

V rozsáhlém panoramatu vědecké činnosti Grzegorze Gazdy vyniká však - jak výše naznačeno - také jeho rusistická tvorba; to byl také jeden $\mathrm{z}$ důvodů, proč jsme ho požádali o členství v redakční radě Nové rusistiky. Magisterský titul za vedení prof. Bolesława W. Lewického získal sice na základě analýzy polského poetického filmu, ale již doktorát získal za práci Futuryzm w Polsce na tle ówczesnych prąów literackich napsanou již za vedení Stefanie Skwarczyńské (recenzenty byli prof. Teresa Cieślikowska, prof. Artur Hutnikiewicz i prof. Michał Głowiński). Gazda se vlastně pohyboval mezi literaturou, divadlem a filmem a mezi literárními směry a žánry. A právě od literárních a uměleckých směrů vedla cesta $\mathrm{k}$ moderně a avantgardě, a tedy k rusistice. Jeho habilitace byla Awangarda - nowoczesność i tradycja. Z teorii i historii europejskich kierunków literackich pierwszych dziesięcioleci $X X$ wieku a ji rozvinul do publikací Futuryzm w Polsce (Ossolineum Wrocław 1972), Awangarda, nowoczesność i tradycja. W kręgu europejskich kierunków literackich pierwszych dziesięcioleci XX wieku (Łódź 1987), Stownik europejskich kierunków $i$ grup literackich $X X$ wieku (Warszawa 2000, 2009), Dwudziestolecie międzywojenne. Stownik literatury polskiej (Gdańsk 2008) a koneckoncủ i do slovníku, který redigoval, a to Stownik rodzajów $i$ gatunków literackich (Kraków 2006, 
2012), kam přispěli i brněnští slavisté. Jak vidno, jeho doménou byla polská literatura, polský film, polská avantgarda, konkrétně polský futurismus, a tu nemohl minout ruskou avantgardu a ruský futurismus a s ním spřízněné umělecké směry, jimiž ruská literatura spolu s výtvarným uměním a architekturou opět - po tzv. zlatém věku a ruském realismu a románu - stanula $\mathrm{v}$ čele světového literárního a obecně uměleckého (týkalo se to $\mathrm{v}$ určitém smyslu i hudby) vývoje. Uvádět konkrétní jména by bylo vožením sov do Athén (egofuturismus, kubofuturismus, konstruktivismus, abstrakcionismus, a přece jen pár jmen: Vladimir Majakovskij, Velimir Chlebnikov, Alexej Kručonych, Vasilij Kandinskij, Kazimir Malevič, Marc Chagall). Také analýzu žánrů opíral o ruskou literaturu, která do jejich podoby vnesla silné inovativní prvky. Své docenění role ruské literatury vyjádřil $\mathrm{v}$ knize Awangarda, nowoczesność i tradycja slovy „... przykład literatury rosyjskiej [...] potwierdza bezpośrednią zależność wysokiej rangi symbolizmu i wysokiej rangi awangardowej formacji poetyckiej, jaka po nim nastąpiła" [GAZDA 1987 , 183]. Stojí za to připomenout, že Gazda komentoval vliv marxismu a revoluční situace, jež avantgardu utvářely (proletářská literatura, ale také futurismus, konstruktivismus a surrealismus) - sami autoři byli s radikální levicí osobně úzce spjatí. Gazda byl také jedním z mála badatelů, kteří komparovali polský, ruský a český (sic!) futurismus: zvláště český futurismus, jenž donedávna čeští bohemisté v dějinách české literatury ani nevydělovali jako speciální směr zaujímající pozici na úrovni poetismu nebo surrealismu (koneckonců řada děl tradičně přiřazovaných $\mathrm{k}$ těmto směrům, má futuristické podloží: S. K. Neumann: Nové zpěvy, 1918; V. Nezval: Edison, 1927; J. Seifert: Na vlnách TSF; 1925 aj.). To, že Poláci, $v$ jejichž literatuře byl futurismus silný, nacházejí tyto rysy i v české literatuře, zatímco ruská je de facto pro obě literatury předlohou - doložila až později speciální publikace polské bohemistky ([GWÓŹDŹ-SZEWCZENKO 2009], viz naši recenzi [POSPÍŠIL 2011]). Grzegorz Gazda byl tak - kromě širokého, již zmíněného rozpětí - také významným rusistou, znalcem ruské a mezinárodní avantgardy a předjímal budoucí práce o českém futurismu.

Ivo Pospišil

\section{Bibliografie:}

POSPÍŠIL, I. (2011): Ilona Gwóźdź-Szewczenko: Futuryzm w czeskim pejzażu literackim. Wydawnictwo Uniwersytetu Wroctawskiego, Wroctaw 2009 (recenze). STIL 10, Beograd 2011, s. 357-358. POSPÍŠIL, I. (2020): Památce Grzegorze Gazdy. Slavica litteraria, 2020, č. 2, s. $171-172$.

GAZDA, G. (1987): Awangarda, nowoczesność i tradycja: $w$ kregu europejskich kierunków literackich pierwszych dziesięcioleci $X X$ w. Łódź.

GWÓŹDŹ-SZEWCZENKO, I. (2009): Futuryzm $w$ czeskim pejzażu literackim. Wrocław. 